\title{
Analysis Of Criminal Liability Crime of Legislative Elections (Case Study Legislative Elections in Semarang)
}

\author{
Nur Muchammad ${ }^{1}$ and Munsharif Abdul Chalim²
}

Abstract. This study aims to determine the form of criminal responsibility to the crime of legislative elections in Semarang; and obstacles in the implementation of criminal law enforcement against criminal acts of the legislative elections in the city of Semarang.

The results showed that the process of law enforcement against criminal acts in general legislative elections held in the context of the criminal justice system in Indonesia, which includes the process of investigation by the police, prosecution by prosecutors and sentencing / verdict by the District Court. Criminal investigations are conducted legislative elections Police, in accordance with the provisions of Article 1 Paragraph (13) of Act No. 2 of 2002 on the Indonesian National Police. In the organization of the legislative elections, in the enforcement of the criminal acts of the legislative elections undergone many obstacles such as: Non-fulfillment of formal requirements and substantive a report criminal election, which resulted election supervisors or investigators difficulty to follow up a report, on terms materially one of them seek witnesses were very hard done by the Election Supervisory; The absence of witnesses because people who know the incident did not dare to testify due to intimidation;

The limited time handling criminal offense elections, at both or election supervisory level law enforcement officers.

Keywords: Criminal Liability; Crime; Legislative Election.

\section{Introduction}

Elections are important in a democratic country, because it is associated with three main functions: (1) political legitimacy, through elections, the legitimacy of the government or the ruling was confirmed as the elected government is essentially a choice most people who have sovereignty. (2) Circulation of the political elite. Election, the circulation or turn the power elite do justly, because the residents state that directly determine who is still considered to be qualified as the political elite and who is not. (3) Political education. Elections serve as a tool for political education for citizens to understand their political rights and obligations. With involvement in the election process, is expected to citizens will receive direct instruction on how citizens should take part in the democratic system. ${ }^{3}$

The context of the electoral system and party system can not be separated from the systemthe government of a country. The system of government influence a person's

\footnotetext{
${ }^{1}$ Student Master of Law, Unissula, Email: muchammadnur1610@gmail.com

${ }^{2}$ Faculty of Law Universitas Islam Sultan Agung

${ }^{3}$ Hikam, Muhammad A.S, 2002, Politik Kewarganegaraan, Landasan Redemokratisasi di Indonesia. Jakarta, Penerbit Bentara, p. 7.
} 
means or method to obtain the highest power and other strategic positions. In the system of democratic government gained power through the electoral system with some of the party that followed, the power is in the hands of the people. People in a democracy become a central point because in essence of democracy is a government that carried out of, by and for the people. Indonesian government implement the system in running a democratic system of government. Democracy is a form of government in which the right to make political decisions held by citizens through representatives chosen by the people and is accountable to the people through an election process that is free. Meaning that, democracy is a system that puts the power over the people through existing representation in parliament directly elected in a general election. ${ }^{4}$ With the provisions of the Constitution NRI elections in 1945 would ensure a regular administration of the election period of five years and better ensure the quality of the processes and mechanisms as well as 4 elections. Since the days of the old order to the new order. The elections had been held one general election of DPR, DPD and DPRD. Implementation the elections over the years did not rule violation, whether the violation or infringement of an administrative nature in the form of a criminal offense.

Criminal election in Indonesia in its development through many changes in the form of an increase in criminal until differences on the addition of criminal sanctions. This is because the more the criminal election increasingly become increasingly serious concern because the measure of success of the democratic state held his views on the success of the election. The government then tighten the law on elections to further aggravate criminal sanctions for perpetrators of criminal election. Furthermore, with the hopean that with the Act No. 8 of 2012 as Law. The latest law on election of members of DPR, DPD and DPRD as the rules of elections that have been refined from the previous Law. This Act has been anticipating the event of a crime and affirmed that there are 4 (four) institutions involved in handling the criminal case elections Supervisory Committee Election (Panwaslu), police, prosecutors, and courts.

It can be said that criminal election is seen as something forbidden act of serious nature and should be completed within 7 short, in order to achieve the purpose of organized criminal provisions to protect the democratic process through elections. As stipulated by the reforms, that the holding of elections for the future must be made and implemented in a better quality. In the elections despite the law. Law and special regulations concerning the elections in order to run properly, but there are still some violations and fraud. Violations and fraud was done by the organizers of the election, the election participants even by the people themselves., In this case study the authors focus on the subject of the offenses of criminal responsibility in legislative elections in Indonesia.

Based on the description on the background of the above problems, it can be molded formulation of the problem as follows: 1 ) What forms of criminal responsibility to the crime of legislative elections in the city of Semarang ?; 2) What are the obstacles in the implementation of criminal law enforcement against criminal acts of the legislative elections in Semarang?

\footnotetext{
${ }^{4}$ Rahman, Arifin, 2006, Sistem Politik Indonesia, Surabaya, SIC, p. 21.
} 


\section{Research methods}

Research is a long process of human endeavor to achieve the desired goal, then it is necessary methods of research into a study. So that researchers get good results then can not be separated from a correct method, which methods are appropriate to the issues to be studied.To conduct the assessment in this study the authors used sociojuridical methods.

\section{Results and Discussion}

\subsection{Against Crime Criminal Liability of Legislative Elections in Semarang}

Criminal liability is essentially an implementation of one's responsibility to accept any risk or juridical consequences that arise as a result of criminal offenses committed. The criminal liability requires the ability to be responsible actors. ${ }^{5}$ In principle, criminal responsibility is the same as talking about mistakes is a fundamental principle in criminal law, which postulates that there is no punishment without fault. Accountability criminal acts as a form of accountability for criminal acts a person who has allegedly committed the crime. Indeed criminal liability concerns not only the purely legal matter, but also concerned about moral values or common decency embraced by communities or groups in society. ${ }^{6}$

With respect to the ability of responsibility in which everyone will be held accountable before the law for what he has done. In this case not everyone can be the subject of criminal law, because that can only be the subject of law is the condition that the person must be proficient in performing legal acts in another sense is able to distinguish between good and bad, included in the crime of legislative elections. There are several groups of people by positive law has been declared incapable or less capable to act alone in performing legal acts, but they should be represented and assisted by others. Those who by law is declared incompetent to do their own legal actions are the ones who are minors or minors under the law, and people who are not healthy mind (crazy). In addition to the two groups so everyone can or legally competent and should be held accountable.

The process of law enforcement against criminal acts in general legislative elections held in the context of the criminal justice system in Indonesia, which includes the process of investigation by the police, prosecution by prosecutors and sentencing / verdict by the District Court. Criminal investigations legislative elections are conducted Police, in accordance with the provisions of Article 1 Paragraph (13) of Act No. 2 of 2002 on the Indonesian National Police, the investigation is a series of actions the investigator in the case and in the manner set out in the legislation to find and collect evidence with evidence that shed light on crime that happened and in order to find the suspects. ${ }^{7}$

\footnotetext{
${ }^{5}$ Harifin A Tump, 2015, Penerapan Konsep Rechtsvinding dan Rechtsschepping oleh Hakim dalam Memutus Suatu Perkara, Halrev Journal of Law, 1 (2).

${ }^{6}$ B. Hestu Cipto Handoyono, 2003, Hukum Tata Negara, Kewarganegaraan \& Hak Asasi Manusia, Cetakan I, Universitas Atmajaya, Yogyakarta, p. 20.

${ }^{7}$ Act No. 2 of 2002 on the Indonesian National Police.
} 
According to Article 1 Paragraph (10) of Act No. 2 of 2002of the Indonesian National Police, the investigator is the Indonesian National Police officers who are authorized by law to conduct an investigation. Assistant Police investigators are officials appointed by the Head of the Indonesian National Police based on the terms of rank and given certain powers in the conduct of the investigation set out in legislation. Investigations carried out to search for and collect evidence on the first stage should be able to provide confidence, although still temporary in nature, to the public prosecutor about what actually happened or about the crime have been carried out and who the suspects. The purpose of investigation in concrete actions investigations can be specified as an action taken by the investigator to get information on the crime of what was done, when the offenses are committed, with what offenses are committed, how the offenses are committed, why the offenses are committed and who the maker or a crime legislative elections.

Investigations of criminal offenses legislative elections are part of police duties as law enforcers who do their utmost to perform a variety of strategic and constructive steps in order to realize security in the country, which includes maintenance of security and public order, order and the rule of law. Investigations of criminal offenses legislative elections, held after receiving a report from the Election Supervisory Committee $1 \times 24$ hours since it was decided in a plenary session discussion on Sentra Gakkumdu in order to obtain strong evidence to determine whether a criminal offense including legislative elections. On the basis of these reports and then the police do the stages of investigation for 14 (fourteen) days to uncover the crime of legislative elections relating to criminal procedure include provisions on data investigations, provisions on knowing the offense, examination at the scene, calling the suspect or defendant, temporary detention, search, inspection or investegasi, news events (searches, interrogations, and spot checks), confiscation and transfer of cases. ${ }^{8}$

Election of criminal law enforcement mechanisms must meet the principles of democracy, then any verdict must always meet at least three (3) important perspectives include: material criminal law perspective, the perspective of formal criminal law and the perspective of the implementation of punishment. ${ }^{9}$ First, the perspective of the criminal behavior of the material which is punishable by criminal, who can be imprisoned and various kinds of punishment that can be imposed. In other words, material criminal law contains norms and sanctions of criminal law as well as general provisions that limit, expand or explain norms and the criminal. Second, the perspective of formal criminal (criminal law adjective) or commonly also called the law of criminal procedure, which could mean the entire regulatory load means the State in exercising its right to enforce the criminal law with implications for the imposition of sanctions for offenders of criminal law materially. Third, the perspective of criminal enforcement or criminal prosecution can not be separated from the criminal justice system (criminal justice system). Article 270 Criminal Procedure Code stipulates that

\footnotetext{
${ }^{8}$ Results Interview With a sub-section of the Law, Public Relations, and Int.Relation, Bawaslu Central Java Province, On February 10, 2019 Date.

${ }^{9}$ Dedi Mulyadi, 2013, Perbandingan Tindak Pidana Pemilu Legislatif dalam perspektif hukum di Indonesia, Cetakan Kesatu, Bandung, PT Refika Aditama, p. 276.
} 
prosecutors who carry out the court decision. How do you implement the decision of the prosecutor are set out in the regulations implementing the Criminal Code or in other words the prosecutor did not become the public prosecutor for a case should implement the Court ruling.

Basically Election law enforcement requires criminal act Electoral divisions are divided into two (2) categories: criminal offense and a felony offense. With legal mechanisms events also show a brief examination and regular checkup event. Especially for the crime of electoral then permanently residing judicial level with the High Court decision berisifat final and binding. In addition a special prosecutor prosecutors is placed in electoral watchdog whose job instituting proceedings directly against the special police investigation results were also placed in the general election supervisor of elections. ${ }^{10}$

\subsection{Obstacles in Implementing the Criminal Law Enforcement Against Crime legislative elections}

The role of the Election Supervisory Body (Bawaslu) as a supervisory institution Election permanent (fixed) and the officers under the Election Supervisory Committee (Panwas/u) either at the district or city, District and Supervision of Elections (PPL) at the village level ad hoc (temporarily) in the handling of allegations of electoral criminal offense is the entrance to the electoral law enforcement system involving the police and the judiciary. In this position, the electoral watchdog institutions (Bawaslu or Panwas/u) often experience problems with time limitations in handling the alleged criminal offense Election, there was no authority to seize evidence and no power to compel witnesses to testify. ${ }^{11}$

AGO in the 2014 election, with police responding to conditionsand Supervisory Committee formed a unified law enforcement centers (Centers Gakkumdu) to streamline coordination between institutions involved in the handling of a criminal offense elections. Memorandum of understanding with the Indonesian General Elections Supervisory Board, the National Police and the Attorney General No. KEP-005 / A / JA / 01/2013 on the Integrated Law Enforcement Sentra. In accordance MoU, Sentra Gakkumdu function is as a forum for coordination in the process of handling criminal offense Election, implementation patterns Election criminal act itself, data centers, increased competence, monitoring-evaluation. While the pattern of handling criminal not been specified in the general election and the Standard Operating Procedure (SOP) on the Crime of Election on Sentra Gakkumdu.

According to the SOP Sentra Gakkumdu, handling criminal offense Election implemented through three (3) stages: a) Acceptance, assessment and delivery of reports / findings of a criminal act to the Election Supervisory Election; Election Supervisory authorities receiving reports or findings of alleged election violations that allegedly contains elements of the crime of Election, by pouring in a Complaint Form.

\footnotetext{
${ }^{10}$ Results Interview With a sub-section of the Law, Public Relations, and Int. Relation, Bawaslu Central Java Province, On February 10, 2019 Date

${ }^{11}$ Bagus Sarwono, 2014, Teknis Media Massa dan Ormas dalam Pengawasan Partisipatif: Guna Mendukung Pengawasan Pemilu, dalam Imam Akbar Awn, dkk (editor), Pengawasan Pemilu Problem dan Tantangan, Yogyakarta: Bawaslu DIY.
} 
After receiving the report or findings of any alleged criminal offense Election, Electoral Supervisory immediately coordinate with the Sentra Gakkumdu and submit the report or the findings of the Sentra Gakkumdu within a maximum period of 24 hours from receipt of the report / findings. b) Follow-up Sentra Gakkumdu to report / findings of alleged criminal election; in this stage of the discussion by the Center Gakkumdu with Sentra Gakkumdu led by members who represent the Supervisory Elections. Meeting participants discuss and provide advice and opinion on the formal and material requirements, clause applied and the fulfillment of electoral criminal elements. c) Follow-up to the recommendations of the Election Supervisory Sentra Gakkumdu, in this stage are arranged on Sentra Gakkumdu, which determines whether a report or findings of an alleged criminal act Election or not, or whether the report or the findings need to be supplemented with formal requirements or conditions materially.

Handling mechanism to the synergy between such institutions is expected to effectively and efficiently respond to various constraints handling criminal offense elections have feared happened. especially concerns about the application of the rules of disagreement between the supervisor with the Police and Attorney General Election.In the organization of the legislative elections, in the implementation of law enforcement against criminal acts of the legislative elections undergone many obstacles such as: ${ }^{12}$

- Non-fulfillment of formal and substantive requirements of a report criminal election, which resulted in the election supervisor or investigator difficult to follow up a report, on terms materially one of them looking for witnesses was very hard done by Bawaslu because Bawaslu itself does not have a forced attempt to summon witnesses witnesses so that the study results are sometimes incomplete. As for the subsequent process stages namely stage of the investigation by the police, the police request data / docket of the Election Supervisory Body must be complete;

- The absence of witnesses because people who know the incident did not dare to testify due to intimidation, while the election supervisors have no authority to protect witnesses. The absence of this witness is the greatest obstacle in law enforcement. Alleged criminal election can only be followed if there is a minimum of two (2) witnesses;

- The limited time handling criminal offense elections, at both or election supervisory level law enforcement officers. One side with limited time handling criminal election violation advantageous because the turnaround time becomes shorter, but on the other hand the time constraints make it difficult for election monitors in an effort to seek kelengkpan evidence and witnesses. Because of the limited time because of the electoral operations in a very short period of time, then in the process of completion must use a short time, so as not prolonged beyond the deadline of the general election.

\footnotetext{
${ }^{12}$ Results Interview With a sub-section of the Law, Public Relations, and int. relation, Bawaslu Central Java Province, On February 10, 2019 Date.
} 
Election criminal case management coordination between law enforcement agencies is necessary given their limitations in handling cases Election criminal but it also should be noted that sometimes the criminal offense involving Election community leaders so handling must be done carefully to avoid possible conflict in society. In handling the criminal case, prosecutors have a responsibility in terms of the burden of proof in the trial later.

\section{Closing}

\subsection{Conclusion}

- The process of law enforcement against criminal acts in general legislative elections held in the context of the criminal justice system in Indonesia, which includes the process of investigation by the police, prosecution by prosecutors and sentencing / verdict by the District Court. Criminal investigations are conducted legislative elections Police, in accordance with the provisions of Article 1 Paragraph (13) of Act No. 2 of 2002 on the Indonesian National Police.

- In the organization of the legislative elections, in the implementation of law enforcement against criminal acts of the legislative elections undergone many obstacles such as:

- Non-fulfillment of formal and substantive requirements of a report criminal election, which resulted in the election supervisor or investigator difficult to follow up a report, on terms materially one of them looking for witnesses was very hard done by Bawaslu.

- The absence of witnesses because people who know the incident did not dare to testify due to intimidation;

- The limited time handling criminal offense elections, at both or election supervisory level law enforcement officers.

\subsection{Suggestion}

The Supervisory Committee, the Commission, the Police and all interested parties in the election should be able to actually carry out duties as instructed. The judge in the criminal dropping against the election organizers should have to really look at all the aspects based on the rule of law, expediency and justice of law, so that justice can be achieved sebenarbenarnya and can be felt by all parties.

\section{Bibliography}

[1] Bagus Sarwono, 2014, Teknis Media Massa dan Ormas dalam Pengawasan Partisipatif: Guna Mendukung Pengawasan Pemilu, dalam Imam Akbar Awn, dkk (editor), Pengawasan Pemilu Problem dan Tantangan, Yogyakarta: Bawaslu DIY.

[2] B. Hestu Cipto Handoyono, 2003, Hukum Tata Negara, Kewarganegaraan \& Hak Asasi Manusia, Cetakan I, Universitas Atmajaya, Yogyakarta

[3] Dedi Mulyadi, 2013, Perbandingan Tindak Pidana Pemilu Legislatif dalam perspektif hukum di Indonesia, Cetakan Kesatu, Bandung, PT Refika Aditama 
[4] Hikam, Muhammad A.S, 2002, Politik Kewarganegaraan, Landasan Redemokratisasi di Indonesia. Jakarta, Penerbit Bentara.

[5] Rahman, Arifin, 2006, Sistem Politik Indonesia, Surabaya, SIC.

[6] Act No. 2 of 2002 on the Indonesian National Police

[7] Harifin A Tump, 2015, Penerapan Konsep Rechtsvinding dan Rechtsschepping oleh Hakim dalam Memutus Suatu Perkara, Halrev Journal of Law. 